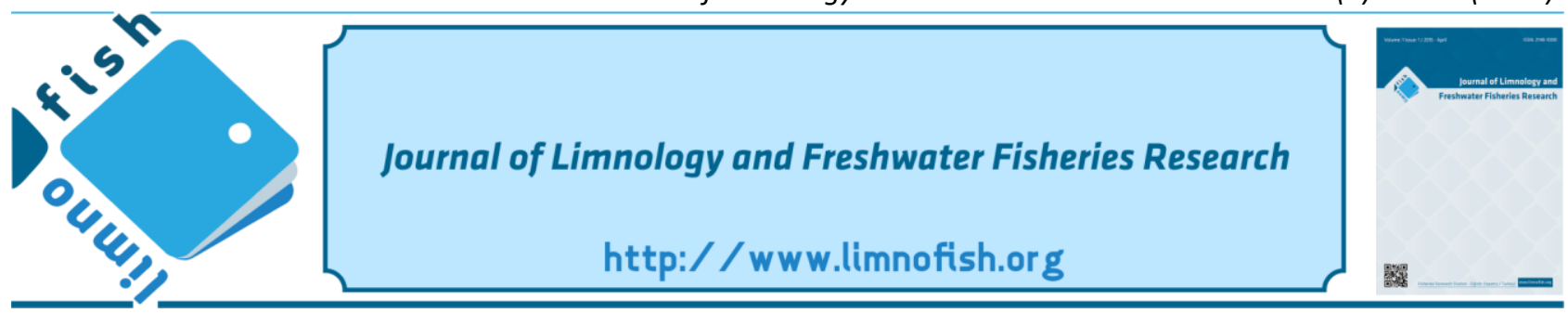

\title{
Zooplankton Diversity of a Sub-Tropical Small Urban Wetland of Meghalaya, Northeast India with Remarks on Spatial Variations
}

\author{
Bhushan Kumar SHARMA ${ }^{1^{*} \text { (D), Sumita SHARMA }}{ }^{2}$ \\ ${ }^{1}$ Department of Zoology, North-Eastern Hill University, Shillong - 793 022, Meghalaya, India \\ ${ }^{2}$ Lady Veronica Road, Shillong - 793 003, Meghalaya, India
}

\section{A B STRACT}

Limnological survey of a small urban wetland of Meghalaya state of northeast India (NEI), undertaken at the littoral and semi-limnetic stations, reveals one of the biodiverse zooplankton assemblages (148 species belonging to 72 genera and 30 families) known from any lentic environ of the Indian sub-region. The speciose nature, peak constellation/sample of 83 zooplankton species, and diverse Rotifera (90 species) are hypothesized to environmental heterogeneity of this urban wetland in contrast to the general pattern of reduced richness expected in highly modified urban aquatic environments. The soft and de-mineralized waters are characterized by low zooplankton abundance. This study records high species diversity and evenness, and low dominance attributed to low and equitable abundance depicts 'generalist' nature of all species. Rotifera > Cladocera and Chydoridae > Lecanidae > Lepadellidae > Daphniidae are important at both stations, and Testudinellidae, Trichocercidae, and Macrothricidae are notable at the littoral station. Individual abiotic factors exert limited and differential spatial influence on various taxa, while the CCA registers a high cumulative influence of 10 abiotic factors on the littoral $(87.37 \%)$ and semi-limnetic $(75.81 \%)$ zooplankton assemblages. The spatial variations of composition, richness, similarities, abundance, diversity indices, and of the influence of individual abiotic factors are hypothesized to habitat heterogeneity amongst the sampled stations.

Keywords: Abundance, diversity indices, habitat diversity, salient features, trophic status

\section{ARTICLE INFO}

$\begin{array}{ll}\text { RESEARCH ARTICLE } \\ \text { Received } & : 17.06 .2020 \\ \text { Revised } & : 22.09 .2020 \\ \text { Accepted } & : 12.10 .2020 \\ \text { Published } & : 29.04 .2021\end{array}$

DOI:10.17216/LimnoFish.754060

\section{* CORRESPONDING AUTHOR}

profbksharma@gmail.com

Phone : +919436110599

\section{How to Cite}

Sharma BK, Sharma S. 2021. Zooplankton Diversity of a Sub-Tropical Small Urban Wetland of Meghalaya, Northeast India with Remarks on Spatial Variations. LimnoFish. 7(1): 24-39. doi: 10.17216/LimnoFish.754060

\section{Introduction}

The smaller water bodies (wetlands and ponds < 10 ha in surface area) form over $90 \%$ of the standing waters of our biosphere and $\sim 30 \%$ of the global lentic biotopes by surface area (Downing et al. 2006). Seekell et al. (2013) and Verpoorter et al. (2014) suggested even higher conservative estimates as high-resolution satellite imagery inventories omit water bodies smaller than 0.2 ha in size, although even the very smallest of these have important roles in ecosystem processes (Holgerson and Raymond 2016). The small urban biotopes are recognized as keystone systems for the conservation of biodiversity (Céréghino et al. 2008, 2014; Vad et al. 2017; Oertli 2018) despite vulnerability to severe threats of extinction and habitat degradation (Moss et al. 2011).
Mullins and Doyle (2019) remarked that limnology will benefit from a renewed focus on these water bodies as they provide valuable ecological services and are likely important hot spots of carbon transformations and carbon sequestration (Downing et al. 2008; Céréghino et al. 2014). The small wetlands are important for maintaining regional biodiversity in urban landscapes that have been highly modified but may not follow the general pattern of reduced taxonomic richness expected in highly modified urban terrestrial or aquatic environments (Hill et al. 2017).

The small wetlands and ponds form an integral part of the rural and urban landscape of India. These environs have attracted relatively more attention since the inception of the Indian limnology and have 
resulted in the proliferation of 'ad-hoc' and 'routine' reports on zooplankton assemblages due to incomplete species lists, unidentified species, limited sampling, and inadequate data analysis (Sharma and Sharma 2019a, 2019b). The selected Indian studies with variable and limited extant of useful information are from small wetlands of Bihar (Kumar et al. 2011; Pandey et al. 2013), Jammu \& Kashmir (Jyoti et al. 2009), Haryana (Tyor et al. 2014; Chopra and Jakhar 2016), Karnataka (Majagi 2014), Telangana (Karuthapandi et al. 2016), Uttarakhand (Kumar et al. 2012) and West Bengal (Datta 2011; Halder Mallick and Chakraborty 2015; Patra et al. 2015; Adhikari et al. 2017; Saha et al. 2017; Midya et al. 2018). Amongst other wetlands, some useful studies are from the floodplains of Bihar (Sanjer and Sharma 1995), Kashmir (Khan 1987; Ahangar et al. 2012; Slathia and Dutta 2013) and West Bengal (Khan 2002, 2003; Ganesan and Khan 2008), while the notable zooplankton diversity works are restricted to the floodplain wetlands of Assam (Sharma and Hussain 2001; Sharma and Sharma 2008, 2012; Sharma 2011a; Sharma and Hatimuria 2017; Sharma and Noroh 2020) and Manipur (Sharma 2011b; Sharma and Sharma 2011) states of NEI. On the other hand, some notable studies from small wetlands of NEI are yet limited to surveys from Meghalaya (Sharma and Wanswet 2006), Arunachal Pradesh (Saikia et al. 2017), and Assam (Deka and Goswami 2015). Also, Sharma et al. (2016), Sharma and Kensibo (2017), and Sharma and Sharma (2019a, 2019b, 2019c) highlighted small wetlands of NEI to be one of the Rotifera biodiversity hot-spots of the Indian sub-region. The literature from India thus reflects the overall paucity of extensive investigations till date on various aspects of zooplankton diversity of small wetlands of India and NEI in general and urban wetlands in particular.

The present study, a follow-up of our survey of the rotifer assemblage (Sharma et al. 2016), endeavors to undertake detailed analyses of zooplankton diversity of a small urban wetland of Meghalaya state of NEI; it assumes biodiversity and limnology interest in light of the stated lacunae. Our study deals with the spatio-temporal variations of richness, species composition, community similarities, abundance, species diversity, equitability and dominance, and individual and cumulative influence of abiotic factors on zooplankton assemblages. The results are discussed vis-a-vis zooplankton diversity of India and of small freshwater environs in particular.

\section{Materials and Methods}

We undertook a limnological survey of a small urban perennial wetland $(\sim 1.5$ ha area; maximum depth: 4 meters) located at the campus of NorthEastern Hill University (NEHU wetland), Shillong the capital of Meghalaya state of NEI (Figure 1, A-B). Water and qualitative and quantitative plankton and semi-plankton samples were collected monthly from the littoral $\left(25^{\circ} 35^{\prime} 33.6^{\prime \prime} \mathrm{N}\right.$; $\left.91^{\circ} 53^{\prime} 46.6^{\prime \prime} \mathrm{E}\right)$ and the semi-limnetic $\left(25^{\circ} 36^{\prime} 30.3^{\prime \prime} \mathrm{N}\right.$; $91^{\circ} 54^{\prime} 01.2^{\prime \prime E}$ ) stations during August 2014-July 2015 from this wetland which lacked limnetic features. The littoral station showed growth of Myriophyllum verticillatum, Nelumbo nucifera, and Hydrilla verticillata and the semi-limnetic station indicated Hydrilla verticillata, Ipomoea aquatica, Nymphoides indica, and Spirogyra sp.

Water samples collected from the two stations were examined for 13 abiotic parameters each. Water temperature was recorded using a centigrade thermometer; $\mathrm{pH}$ and specific conductivity were recorded with the field probes; dissolved oxygen was estimated by the modified Winkler's method, and other abiotic factors namely total alkalinity, total hardness, calcium, magnesium, chloride, dissolved organic matter, total dissolved solids, phosphate, and nitrate were analyzed following APHA (1992). The qualitative plankton and semi-plankton samples, collected from each sampling station by towing nylobolt plankton net (mesh size: $40 \mu \mathrm{m}$ ), were preserved in 5\% formalin. All samples were screened with a Wild stereoscopic binocular microscope, zooplankton taxa were isolated and mounted in polyvinyl alcohol-lactophenol mixture, and were observed with Leica (DM 1000) stereoscopic microscope. Zooplankton species were identified following Michael and Sharma (1988), Sharma (1998, 2016), Sharma and Sharma (1999a, 1999b, 2000, 2008), and Sharma et al. (2016). The community similarities were calculated vide Sørensen's index and the hierarchical cluster analysis was done using SPSS (version 20). Monthly quantitative samples were obtained from the two stations by filtering $25 \mathrm{~L}$ of water each through nylobolt plankton net and were preserved in 5\% formalin. Quantitative enumeration of zooplankton and constituent taxa was done by using a SedgewickRafter counting cell. The abundance of various taxa was expressed as $\mathrm{n} / \mathrm{l}$ as well as ranges and mean \pm S.D. Species diversity (Shannon Weiner's index), dominance (Berger-Parker's index) and evenness $\left(\mathrm{E}_{1}\right.$ index $)$ were calculated vide Ludwig and Reynolds (1988) and Magurran (1988). Two-way analysis of variance (ANOVA) was used to ascertain significance of spatio-temporal variations of abiotic and biotic parameters between the sampled stations and months. Pearson's correlation coefficients for the two stations ( $r_{1}$ and $r_{2}$, respectively) were calculated between abiotic and biotic factors; $p$ values were 
calculated vide http://vassarstats.net/tabs.html and their significance was ascertained after applying Bonferroni corrections. The canonical correspondence analysis was done using XLSTAT (version 2015) to record the cumulative influence of 10 abiotic factors (for logistic limitations of the study period): water temperature, $\mathrm{pH}$, specific conductivity, dissolved oxygen, total alkalinity, total hardness, chloride, dissolved organic matter, total dissolved solids and phosphate on zooplankton assemblages.
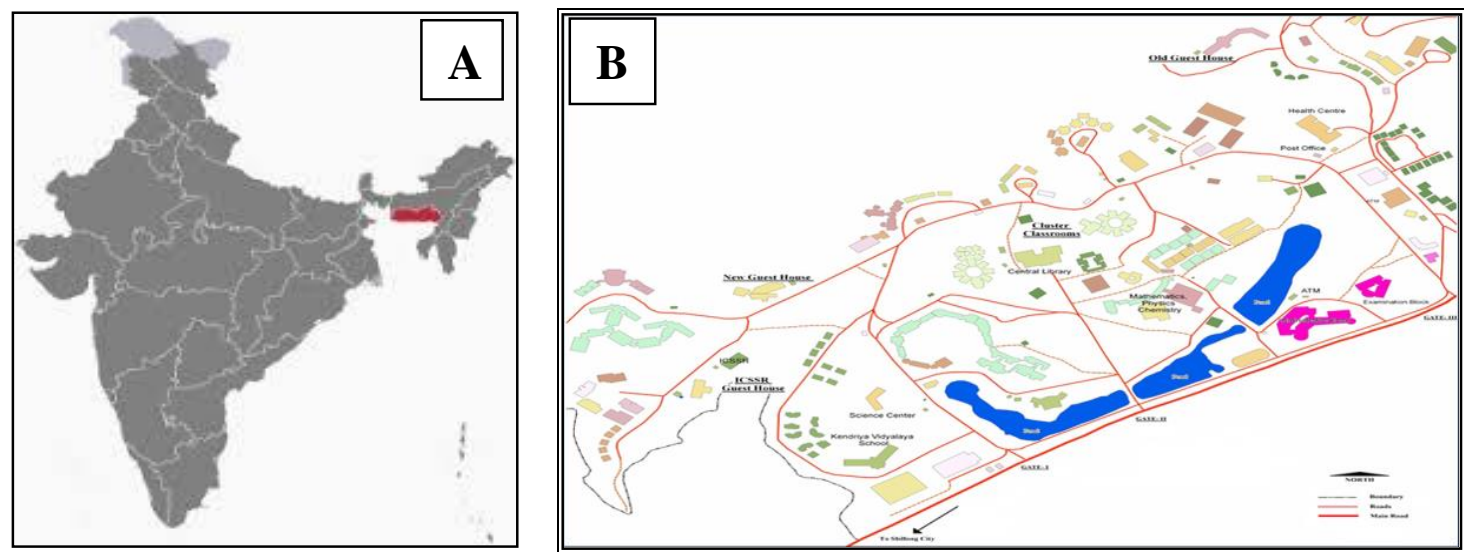

Figure 1. A, map of India showing the state of Meghalaya (red color); B, campus map of North-Eastern Hill University, Shillong showing NEHU urban wetland (blue color).

\section{Results}

Water temperature ranged between $12.0-22.5^{\circ} \mathrm{C}$, $\mathrm{pH}$ between 6.02-6.99, specific conductivity between 31.0-51.0 $\mu \mathrm{S} / \mathrm{cm}$, dissolved oxygen between $5.6-7.6 \mathrm{mg} / \mathrm{l}$, total alkalinity between $18.0-30.0 \mathrm{mg} / \mathrm{l}$, total hardness between 20.0-32.0 mg/l; calcium between $8.4-27.3 \mathrm{mg} / \mathrm{l}$, magnesium between
2.7-19.5 mg/l, chloride between 23.9-37.9 mg/l, dissolved organic matter between $0.038-0.180 \mathrm{mg} / \mathrm{l}$ and total dissolved solids between $0.068-0.160 \mathrm{mg} / \mathrm{l}$ during the study period (Table 1). In addition, phosphate and nitrate varied between $0.209-1.055 \mathrm{mg} / \mathrm{l}$ and 0.356-1.214 $\mathrm{mg} / \mathrm{l}$, respectively (Table 1).

Table 1. Variations of abiotic parameters.

\begin{tabular}{lcccc}
\hline \multirow{2}{*}{ Parameters $\downarrow$ Sampling stations $\rightarrow$} & \multicolumn{2}{c}{ Littoral station } & \multicolumn{2}{c}{ Semi-limnetic station } \\
\cline { 2 - 5 } & RANGE & MEAN \pm SD & RANGE & MEAN \pm SD \\
\hline Water temperature $\left({ }^{\circ} \mathrm{C}\right)$ & $12.0-22.5$ & $17.4 \pm 3.2$ & $12.0-22.5$ & $17.4 \pm 3.2$ \\
\hline $\mathrm{pH}$ & $6.02-6.97$ & $6.43 \pm 0.29$ & $6.40-6.99$ & $6.59 \pm 0.19$ \\
\hline Specific Conductivity. $(\mu \mathrm{S} / \mathrm{cm})$ & $31.0-50.0$ & $34.8 \pm 5.4$ & $32.0-51.0$ & $37.4 \pm 5.4$ \\
\hline Dissolved oxygen $(\mathrm{mg} / \mathrm{l})$ & $5.6-7.6$ & $6.7 \pm 0.5$ & $5.6-7.2$ & $6.3 \pm 0.5$ \\
\hline Total Alkalinity $(\mathrm{mg} / \mathrm{l})$ & $18.0-28.0$ & $22.7 \pm 3.3$ & $20.0-30.0$ & $24.0 \pm 3.5$ \\
\hline Total Hardness $(\mathrm{mg} / \mathrm{l})$ & $20.0-32.0$ & $24.8 \pm 3.6$ & $22.0-32.0$ & $26.3 \pm 3.4$ \\
\hline Calcium $(\mathrm{mg} / \mathrm{l})$ & $8.4-23.1$ & $14.3 \pm 4.6$ & $8.4-27.3$ & $14.3 \pm 6.1$ \\
\hline Magnesium $(\mathrm{mg} / \mathrm{l})$ & $7.0-17.5$ & $10.5-3.1$ & $2.7-19.5$ & $11.9 \pm 4.6$ \\
\hline Chloride $(\mathrm{mg} / \mathrm{l})$ & $24.9-36.9$ & $32.2 \pm 3.6$ & $23.9-37.9$ & $32.5 \pm 4.1$ \\
\hline Dissolved organic matter $(\mathrm{mg} / \mathrm{l})$ & $0.038-0.169$ & $0.103 \pm 0.038$ & $0.038-0.180$ & $0.105 \pm 0.042$ \\
\hline Total dissolved solids $(\mathrm{mg} / \mathrm{l})$ & $0.068-0.128$ & $0.106 \pm 0.015$ & $0.072-0.160$ & $0.107 \pm 0.028$ \\
\hline Phosphate $(\mathrm{mg} / \mathrm{l})$ & $0.251-1.055$ & $0.717 \pm 0.250$ & $0.209-1.035$ & $0.748 \pm 0.247$ \\
\hline Nitrate $(\mathrm{mg} / \mathrm{l})$ & $0.356-1.214$ & $0.780 \pm 0.319$ & $0.503-1.128$ & $0.832 \pm 0.253$ \\
\hline
\end{tabular}

Table 2. Composition of zooplankton.

\begin{tabular}{lccc}
\hline Groups $\downarrow$ Taxa $\rightarrow$ & Species & Genera & Families \\
\hline Rotifera & 90 & 29 & 15 \\
\hline Cladocera & 36 & 28 & 6 \\
\hline Rhizopoda & 10 & 6 & 5 \\
\hline Copepoda & 7 & 4 & 2 \\
\hline Ostracoda & 5 & 5 & 2 \\
\hline Zooplankton & $\mathbf{1 4 8}$ & $\mathbf{7 2}$ & $\mathbf{3 0}$ \\
\hline
\end{tabular}




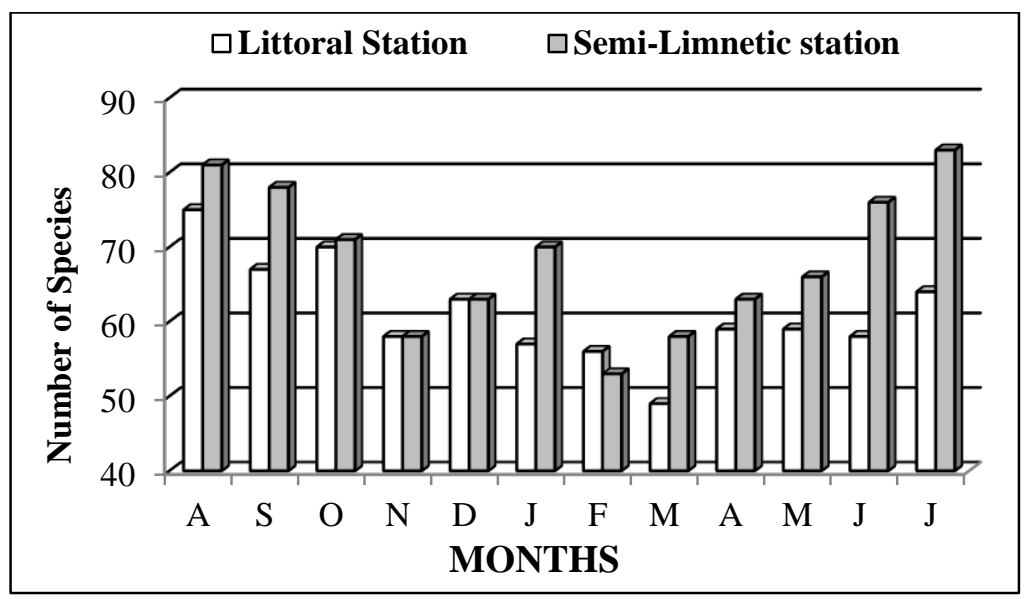

Figure 2. Monthly variations of zooplankton richness.

We observed 148 zooplankton species belonging to 72 genera and 30 families (Table 2-3) with 148 and 122 species from the two sampling stations, respectively. Rotifera, Cladocera, Rhizopoda, Copepoda, and Ostracoda indicate 90, 36, 10, 7, and 5 species, respectively. The monthly zooplankton richness varied between 49-75(61 \pm 7$)$ and 53$83(68 \pm 9)$ species (Figure 2), registered 47.2-74.5\% and 55.7-84.0\% similarities (Table 3) and record notable differences in monthly groupings vide the hierarchical cluster analysis (Figures 3-4). Rotifera and Cladocera (Table 3) record richness between 1635 and 24-46 species; and 19-25 and 18-28 species and community similarities ranging between 19.060.9 and 37.3-79.5 \% and 58.5-94.7 and 71.4-89.5\% at the littoral and semi-limnetic stations, respectively.

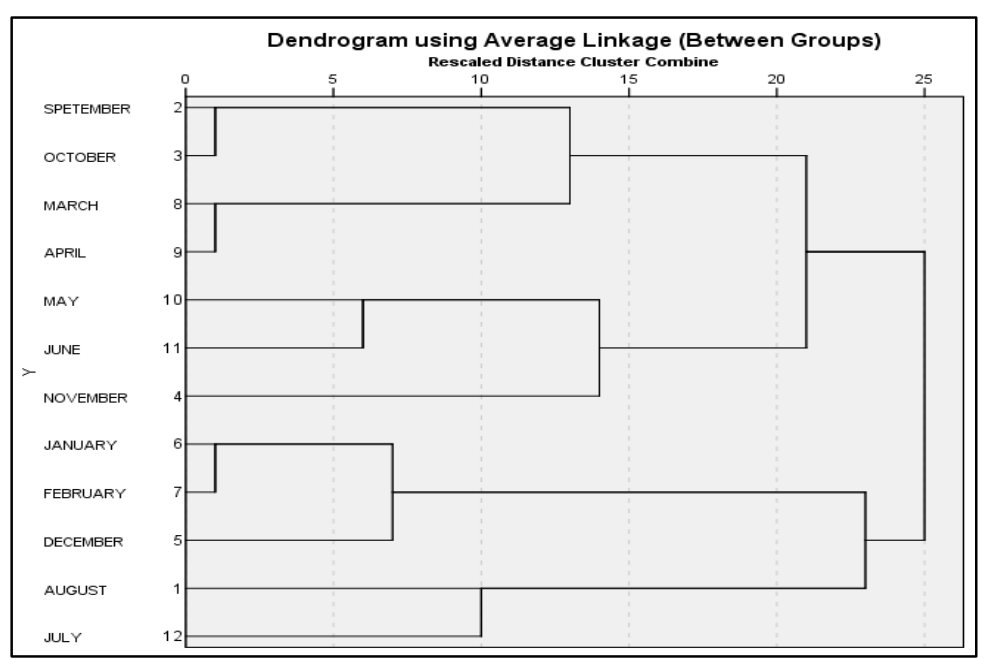

Figure 3. Hierarchical cluster analysis of zooplankton assemblages (Littoral station).

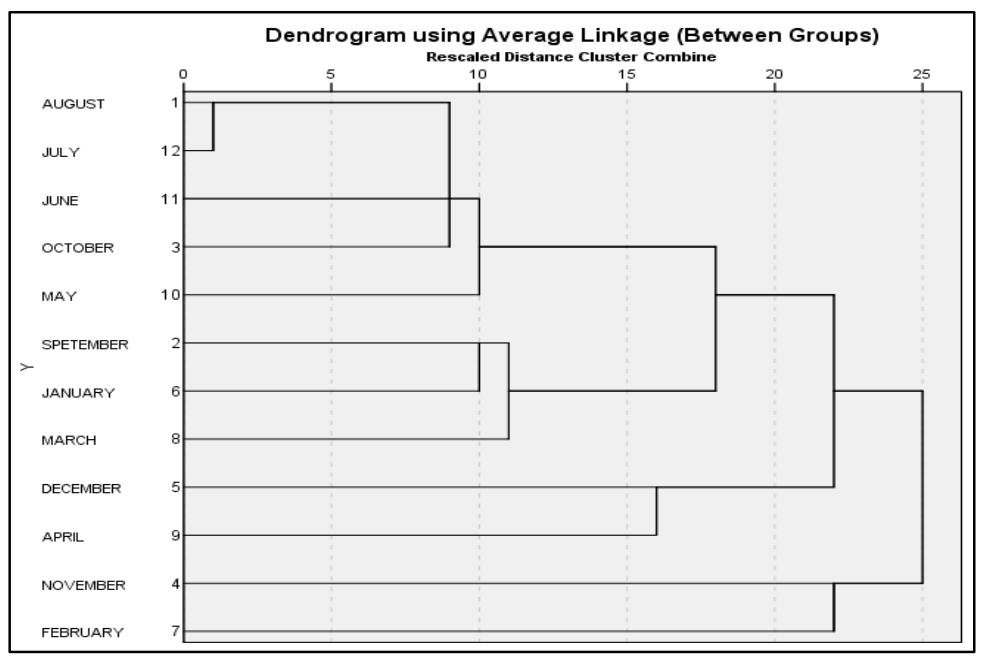

Figure 4. Hierarchical cluster analysis of zooplankton assemblages (Semi-limnetic station). 
The monthly variations in zooplankton abundance and diversity indices are indicated in Table 3. The abundance ranged between $208-308 \mathrm{n} / 1$ and 197-245 n/l (Figure 5), species diversity (Figure 6 ), evenness and dominance of zooplankton ranged between 3.469-4.195 and 3.934-4.452, 0.858-0.974 and 0.877-0.995, and 0.030-0.093 and 0.027-0.046 at the littoral and semi-limnetic stations, respectively
(Table 3). Rotifera (64-142 n/l; 71-129 n/l) and Cladocera (82-107n/l; 70-84 n/I) comprised between $42.9 \pm 11.3,44.2 \pm 4.6 \%$, and $40.0 \pm 5.2,38.4 \pm 4.3 \%$ of zooplankton abundance (Figures 7-8); Rhizopoda and Copepoda abundance varied between $20 \pm 4 \mathrm{n} / \mathrm{l}$, $19 \pm 4 \mathrm{n} / 1 ; 21 \pm 3,13 \pm 2 \mathrm{n} / 1$ (Table 3); and Ostracoda $(8 \pm 1,4 \pm 2 \mathrm{n} / \mathrm{l})$ recorded poor abundance at the two stations, respectively.

Table 3. Zooplankton richness, abundance, and diversity indices.

\begin{tabular}{|c|c|c|c|c|}
\hline Groups $\downarrow$ & \multicolumn{2}{|c|}{ Littoral Station } & \multicolumn{2}{|c|}{ Semi-limnetic Station } \\
\hline \multicolumn{5}{|l|}{ Richness } \\
\hline Zooplankton (total richness) & \multicolumn{2}{|c|}{148 species } & \multicolumn{2}{|c|}{122 species } \\
\hline $\begin{array}{l}\text { Zooplankton (monthly) } \\
\text { Community similarity }\end{array}$ & \multicolumn{2}{|c|}{$\begin{array}{c}49-75 \text { species } 61 \pm 7 \text { species } \\
47.2-74.5 \%\end{array}$} & \multicolumn{2}{|c|}{$\begin{array}{c}53-83 \text { species } 68 \pm 9 \text { species } \\
55.7-84.0 \%\end{array}$} \\
\hline $\begin{array}{l}\text { Rotifera (monthly) } \\
\text { Community similarity }\end{array}$ & \multicolumn{2}{|c|}{$\begin{array}{c}16-35 \text { species } 25 \pm 7 \text { species } \\
19.0-60.9 \%\end{array}$} & \multicolumn{2}{|c|}{$\begin{array}{c}24-46 \text { species } 35 \pm 7 \text { species } \\
37.3-79.5 \%\end{array}$} \\
\hline $\begin{array}{l}\text { Cladocera (monthly) } \\
\text { Community similarity }\end{array}$ & \multicolumn{2}{|c|}{$\begin{array}{c}19-25 \text { species } 22 \pm 2 \text { species } \\
58.5-94.7 \%\end{array}$} & \multicolumn{2}{|c|}{$\begin{array}{c}18-28 \text { species } 22 \pm 3 \text { species } \\
71.4-89.5 \% \%\end{array}$} \\
\hline \multicolumn{5}{|l|}{ Abundance and diversity } \\
\hline Zooplankton $(\mathrm{n} / \mathrm{l})$ & $208-308$ & $247 \pm 26$ & $197-245$ & $213 \pm 23$ \\
\hline Species diversity & $3.469-4.195$ & $3.842 \pm 0.192$ & $3.934-4.452$ & $4.135 \pm 0.142$ \\
\hline Evenness & $0.858-0.974$ & $0.943 \pm 0.046$ & $0.877-0.995$ & $0.974 \pm 0.030$ \\
\hline Dominance & $0.030-0.093$ & $0.058 \pm 0.010$ & $0.027-0.046$ & $0.057 \pm 0.017$ \\
\hline \multicolumn{5}{|l|}{ Different Groups } \\
\hline Rotifera $(\mathrm{n} / \mathrm{l})$ & $64-142$ & $98 \pm 7$ & $71-129$ & $81 \pm 7$ \\
\hline$\%$ composition & $29.9-73.9$ & $42.9 \pm 11.3$ & $38.6-52.9$ & $44.2 \pm 4.6$ \\
\hline Cladocera (n/l) & $82-107$ & $58 \pm 18$ & $70-84$ & $66 \pm 17$ \\
\hline$\%$ composition & $14.6-37.9$ & $40.0 \pm 5.2$ & $19.0-52.2$ & $38.4 \pm 4.3$ \\
\hline Rhizopoda (n/l) & $15-28$ & $20 \pm 4$ & $15-28$ & $19 \pm 4$ \\
\hline$\%$ composition & $5.1-9.6$ & $8.1 \pm 1.1$ & $6.3-11.8$ & $9.0 \pm 1.3$ \\
\hline Copepoda (n/l) & $12-25$ & $21 \pm 3$ & $9-18$ & $13 \pm 2$ \\
\hline$\%$ composition & $5.0-11.3$ & $8.0 \pm 1.9$ & $4.6-8.2$ & $6.3 \pm 1.0$ \\
\hline Ostracoda $(\mathrm{n} / \mathrm{l})$ & $6-11$ & $8 \pm 1$ & $1-7$ & $4 \pm 2$ \\
\hline \multicolumn{5}{|l|}{ Different Families (n/l) } \\
\hline Chydoridae & $49-68$ & $59 \pm 6$ & $34-64$ & $52 \pm 7$ \\
\hline Lecanidae & $20-51$ & $39 \pm 9$ & $22-53$ & $37 \pm 9$ \\
\hline Lepadellidae & $7-27$ & $16 \pm 7$ & $12-28$ & $21 \pm 5$ \\
\hline Daphniidae & $11-18$ & $14 \pm 2$ & $7-15$ & $12 \pm 2$ \\
\hline Testudinellidae & $9-24$ & $16 \pm 5$ & $0-12$ & $6 \pm 3$ \\
\hline Trichocercidae & $0-17$ & $10 \pm 5$ & $3-14$ & $8 \pm 3$ \\
\hline Macrothricidae & $8-14$ & $11 \pm 2$ & $4-8$ & $6 \pm 1$ \\
\hline
\end{tabular}

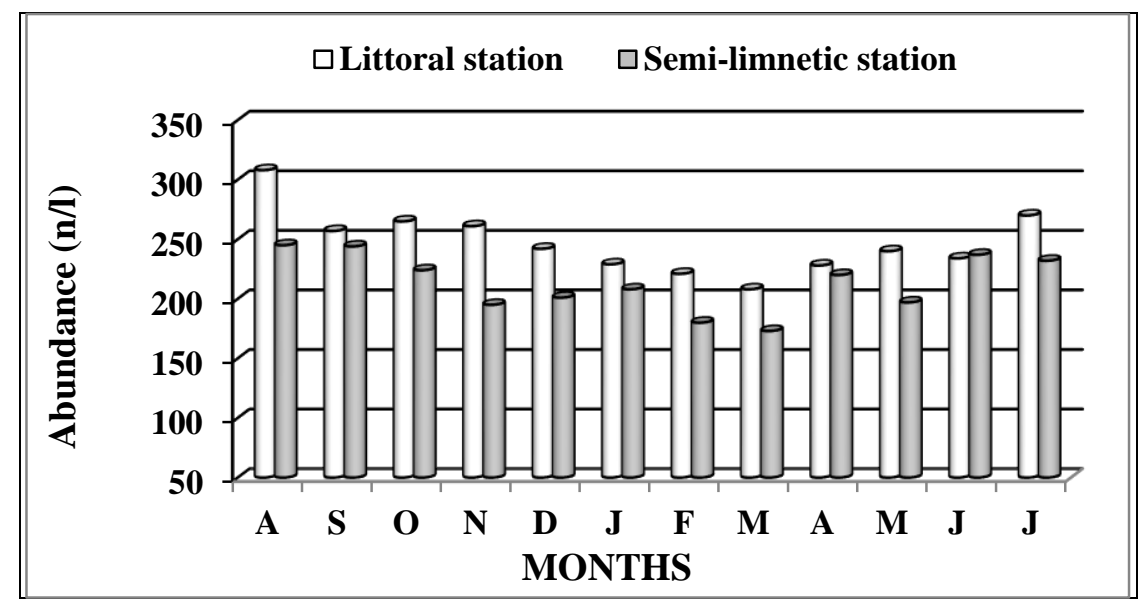

Figure 5. Monthly variations of zooplankton abundance. 
The significance of various abiotic and biotic factors (vide ANOVA) between the littoral and semi-limnetic stations and months are indicated in Table 4.

Table 4. ANOVA indicating the significance of abiotic and biotic factors

\begin{tabular}{|c|c|c|}
\hline Parameters & Stations & Months \\
\hline \multicolumn{3}{|c|}{ Abiotic factors } \\
\hline Water temperature & - & $\mathrm{F}_{11,23}=7.981, \mathrm{P}=8.32 \mathrm{E}-05$ \\
\hline $\mathrm{pH}$ & $\mathrm{F}_{1,23}=5.789, \mathrm{P}=0.034$ & $\mathrm{~F}_{11,23}=3.572, \mathrm{P}=0.022$ \\
\hline Specific conductivity & $\mathrm{F}_{1,23}=14.978, \mathrm{P}=0.003$ & $F_{11,23}=19.526, P=1.12 E-05$ \\
\hline Dissolved oxygen & $\mathrm{F}_{1,23}=3.667, \mathrm{P}=0.081$ & - \\
\hline Total Alkalinity & $\mathrm{F}_{1,23}=5.49, \mathrm{P}=0.039$ & $\mathrm{~F}_{11,23}=11.125, \mathrm{P}=0.0002$ \\
\hline Total Hardness & $\mathrm{F}_{1,23}=11.879, \mathrm{P}=0.005$ & $\mathrm{~F}_{11,23}=20.307, \mathrm{P}=9.9 \mathrm{E}-06$ \\
\hline Calcium & - & $\mathrm{F}_{11,23}=20.047, \mathrm{P}=1.06 \mathrm{E}-05$ \\
\hline Magnesium & - & $\mathrm{F}_{11,23}=6.920, \mathrm{P}=0.002$ \\
\hline Chloride & - & $F_{11,23}=35.850, P=5.26 E-07$ \\
\hline Dissolved organic matter & - & $\mathrm{F}_{11,23}=63.170, \mathrm{P}=2.6 \mathrm{E}-08$ \\
\hline Total dissolved solids & - & $\mathrm{F}_{11,23}=3.622, \mathrm{P}=0.021$ \\
\hline Phosphate & - & $\mathrm{F}_{11,23}=21.024, \mathrm{P}=8.3 \mathrm{E}-06$ \\
\hline Nitrate & - & $\mathrm{F}_{11,23}=35.140, \mathrm{P}=5.84 \mathrm{E}-07$ \\
\hline \multicolumn{3}{|c|}{ Richness } \\
\hline Zooplankton & $\mathrm{F}_{1,23}=11.724, \mathrm{P}=0.005$ & $\mathrm{~F}_{11,23}=4.611, \mathrm{P}=0.008$ \\
\hline Rotifera & $\mathrm{F}_{1,23}=68.075, \mathrm{P}=4.87 \mathrm{E}-06$ & $\mathrm{~F}_{11,23}=11.095, \mathrm{P}=0.0002$ \\
\hline Cladocera & - & - \\
\hline \multicolumn{3}{|c|}{ Abundance and diversity indices } \\
\hline Zooplankton & $\mathrm{F}_{1,23}=31.866, \mathrm{P}=0.0001$ & $\mathrm{~F}_{11,23}=5.010, \mathrm{P}=0.006$ \\
\hline Rotifera & - & $\mathrm{F}_{11,23}=4.642, \mathrm{P}=0.008$ \\
\hline Copepoda & $\mathrm{F}_{1,23}=40.753, \mathrm{P}=5.2 \mathrm{E}-05$ & - \\
\hline Cladocera & $\mathrm{F}_{1,23}=40.745, \mathrm{P}=5.2 \mathrm{E}-05$ & - \\
\hline Zooplankton species diversity & $\mathrm{F}_{1,23}=15.380, \mathrm{P}=0.002$ & - \\
\hline Zooplankton evenness & - & - \\
\hline Zooplankton dominance & - & - \\
\hline \multicolumn{3}{|c|}{ Important families } \\
\hline Chydoridae & $\mathrm{F}_{1,23}=9.580, \mathrm{P}=0.010$ & - \\
\hline Lecanidae & - & $\mathrm{F}_{11,23}=3.664, \mathrm{P}=0.020$ \\
\hline Lepadellidae & - & $\mathrm{F}_{11,23}=3.664, \mathrm{P}=0.020$ \\
\hline Daphniidae & $\mathrm{F}_{1,23}=13.569, \mathrm{P}=0.004$ & $\mathrm{~F}_{11,23}=3.978, \mathrm{P}=0.015$ \\
\hline Testudinellidae & $\mathrm{F}_{1,23}=44.929, \mathrm{P}=3.36 \mathrm{E}-05$ & \\
\hline Trichocercidae & - & $\mathrm{F}_{11,23}=5.045, \mathrm{P}=0.006$ \\
\hline Macrothricidae & $\mathrm{F}_{1,23}=59 . .055, \mathrm{P}=9.55 \mathrm{E}-06$ & - \\
\hline
\end{tabular}

(-) indicates insignificant variations.

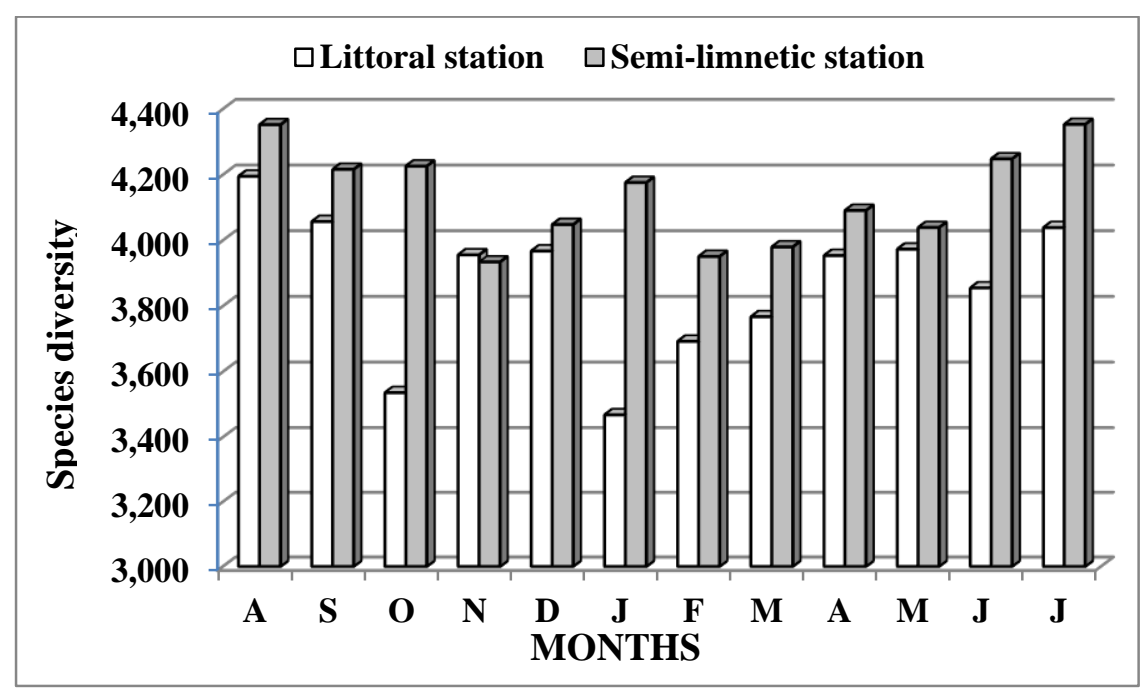

Figure 6. Monthly variations of zooplankton species diversity. 


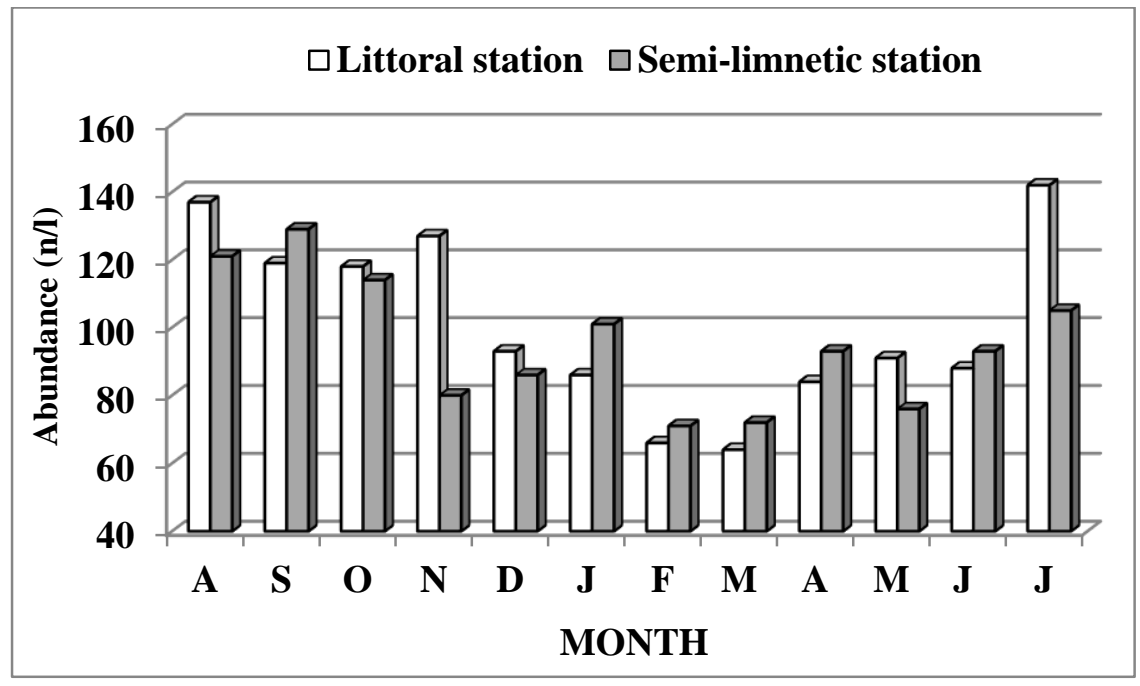

Figure 7. Monthly variations of the abundance of Rotifera.

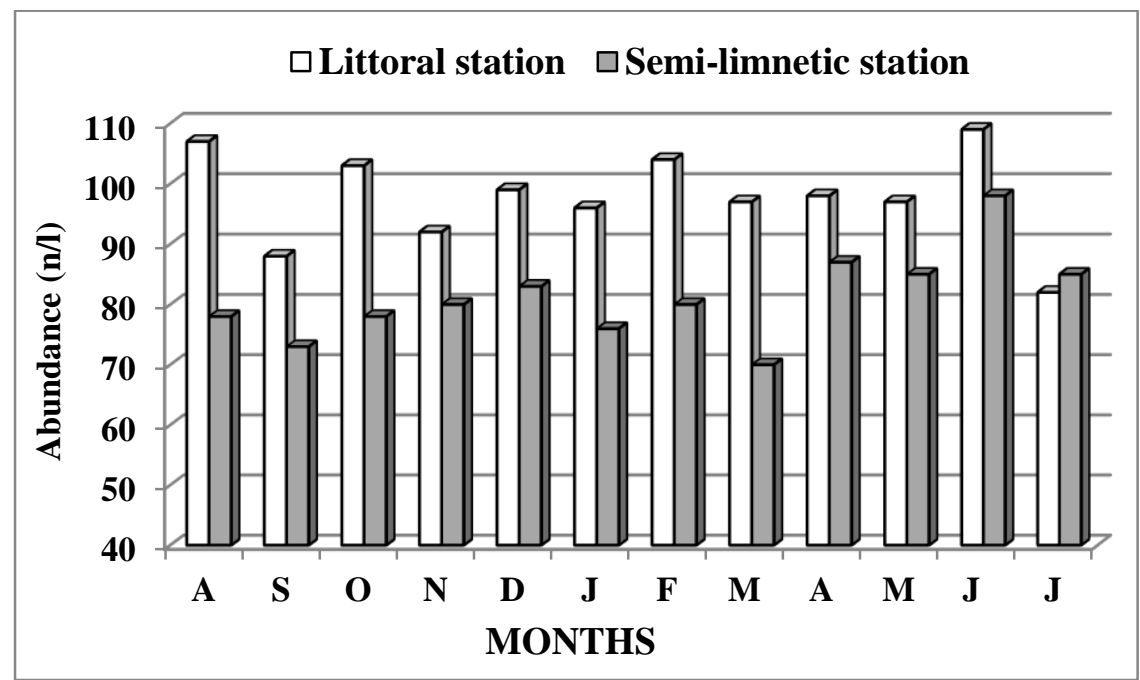

Figure 8. Monthly variations of the abundance of Cladocera.

Chydoridae $(59 \pm 6$ and $52 \pm 7 \mathrm{n} / \mathrm{l})$, Lecanidae $(39 \pm 9$ and $37 \pm 9 \mathrm{n} / \mathrm{l})$, Lepadellidae (16 \pm 7 and $21 \pm 5 \mathrm{n} / \mathrm{l})$ and Daphniidae (14 \pm 2 and $12 \pm 2 \mathrm{n} / \mathrm{l})$ deserved attention at the two stations, respectively. Testudinellidae $(16 \pm 5 \quad \mathrm{n} / \mathrm{l}), \quad$ Trichocercidae $(10 \pm 5 \mathrm{n} / \mathrm{l})$, and Macrothricidae $(11 \pm 2 \mathrm{n} / \mathrm{l})$ recorded importance at Station 1 , while Sidiidae and Brachionidae deserved limited importance.

Zooplankton $\left(\mathrm{r}_{1}=0.729, \mathrm{p}=0.0168\right)$ and Rotifera $\left(\mathrm{r}_{1}=0.874, \mathrm{p}=0.0009\right)$ richness, and abundance of zooplankton $\left(r_{1}=0.789, p=0.0067\right)$, Rotifera $\left(r_{1}=\right.$ $0.813, \mathrm{p}=0.0042)$, Lecanidae $\left(\mathrm{r}_{1}=0.622, \mathrm{p}=0.0548\right)$ and Trichocercidae $\left(r_{1}=0.762, p=0.0104\right)$ are positively correlated with water temperature at the littoral station. In addition, zooplankton $\left(\mathrm{r}_{1}=-0.856\right.$, $\mathrm{p}=0.0016)$ and Rotifera $\left(\mathrm{r}_{1}=-0.757, \mathrm{p}=0.0112\right)$ richness, and abundance of zooplankton $\left(r_{1}=-0.786\right.$, $\mathrm{p}=0.007)$, Rotifera $\left(\mathrm{r}_{1}=-0.668, \mathrm{p}=0.0348\right)$ and
Lecanidae $\left(\mathrm{r}_{1}=-0.808, \mathrm{p}=0.0047\right)$ are inversely correlated with total dissolved solids; zooplankton $\left(\mathrm{r}_{1}=-0.860, \mathrm{p}=0.0014\right)$ and Rotifera $\left(\mathrm{r}_{1}=-0.719\right.$, $\mathrm{p}=0.0191)$ richness, and abundance of zooplankton $\left(r_{1}=-0.849, p=0.0019\right)$ and Rotifera $\left(r_{1}=-0.664\right.$, $\mathrm{p}=0.0363)$ are inversely influenced by dissolved organic matter, while Lecanidae abundance $\left(r_{1}=-0.668, p=0.034\right)$ is inversely correlated with specific conductivity at the littoral station. Zooplankton $\left(\mathrm{r}_{2}=0.838, \mathrm{p}=0.0025\right)$ and Rotifera $\left(\mathrm{r}_{2}=0.755, \mathrm{p}=0.026\right)$ richness, and abundance of zooplankton $\left(\mathrm{r}_{2}=0.837, \mathrm{p}=0.0032\right)$, Rotifera $\left(\mathrm{r}_{2}=0.771, \mathrm{p}=0.009\right)$, Rhizopoda $\left(\mathrm{r}_{2}=0.701\right.$, $\mathrm{p}=0.024)$ and Lecanidae $\left(\mathrm{r}_{2}=0.694, \mathrm{p}=0.026\right)$ is positively correlated with water temperature, and Rotifer density $\left(r_{2}=-0.743, p=0.0138\right)$ is inversely correlated with dissolved organic matter at the semilimnetic station. 


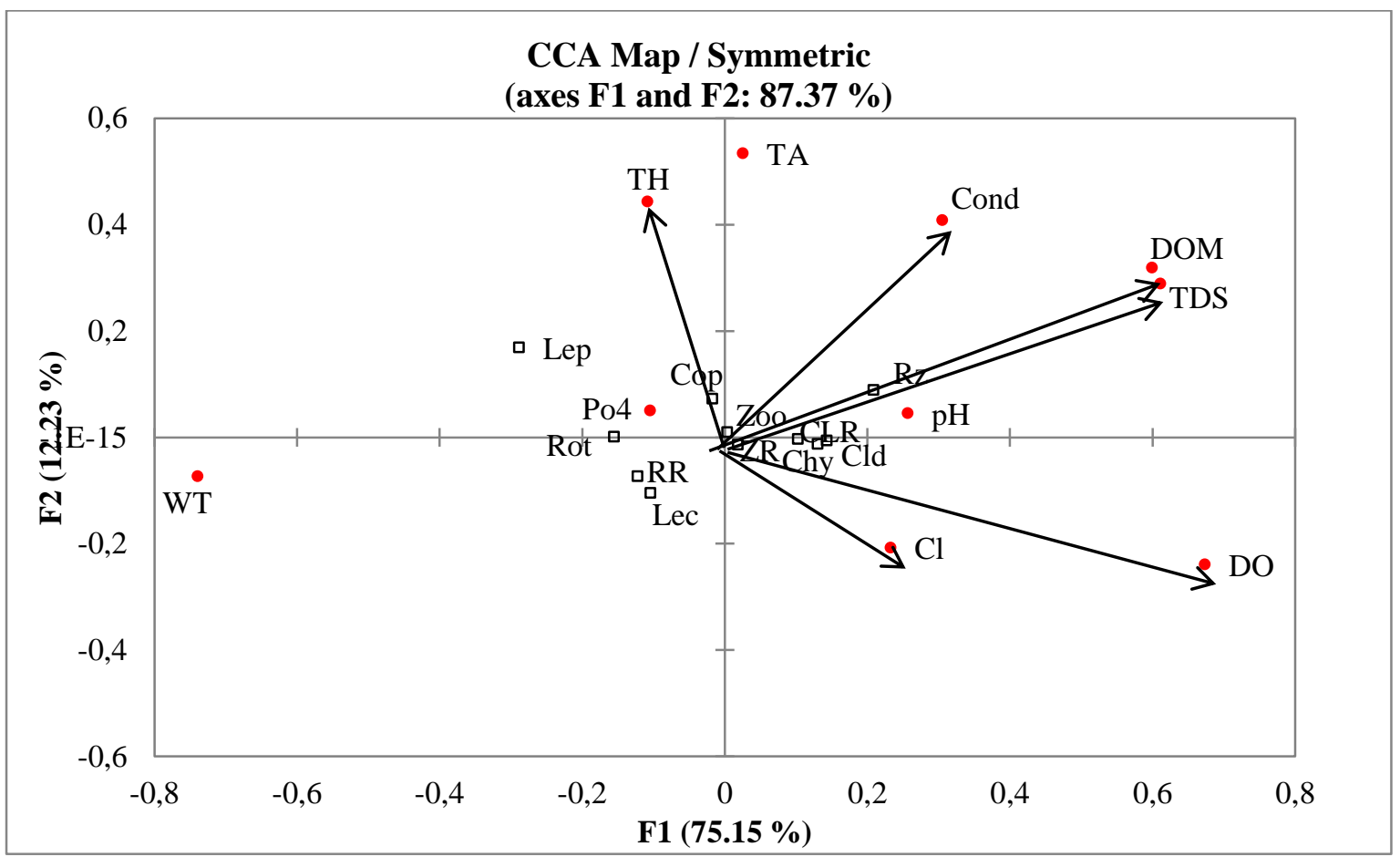

Figure 9. CCA coordination biplot of zooplankton and abiotic factors (Littoral station).

Abbreviations: Abiotic factors: $\mathrm{Cl}$ (Chloride), Cond (specific conductivity), DOM (dissolved organic matter), DO (dissolved oxygen), Po4 (phosphate), TA (total alkalinity), TDS (total dissolved solids), TH (total hardness), pH (hydrogen-ion concentration), Wt (water temperature). Biotic factors: Chy (Chydoridae abundance), Cld (Cladocera abundance), CIR (Cladocera richness abundance), Cop (Copepoda abundance), Lec (Lecanidae abundance), Lep (Lepadellidae abundance), Rot (Rotifera abundance), RR (Rotifera richness), Rz (Rhizopoda abundance), Zoo (Zooplankton abundance), ZR (Zooplankton richness).

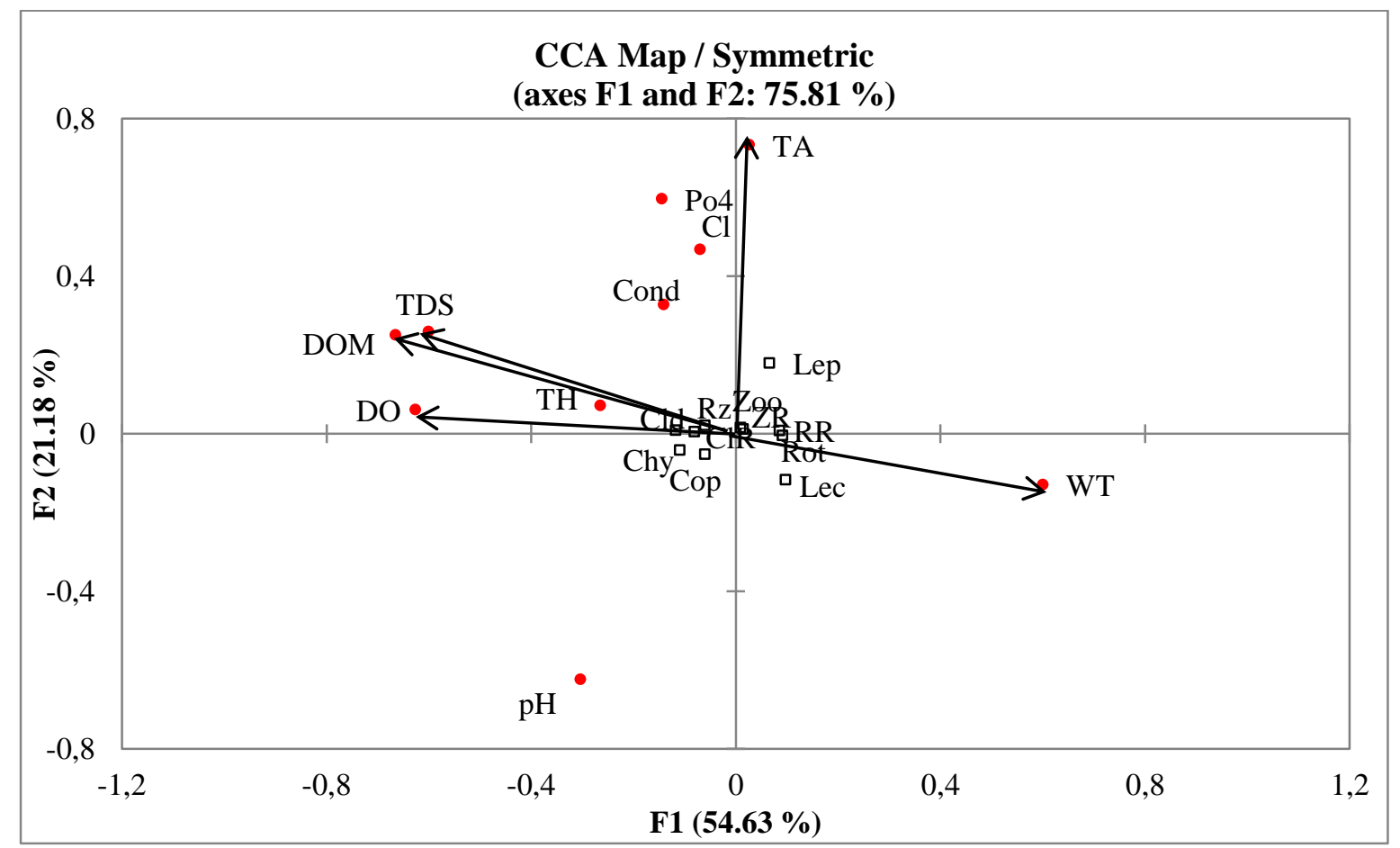

Figure 10. CCA coordination biplot of zooplankton and abiotic factors (Semi-limnetic station)

Abbreviations: Abiotic factors: $\mathrm{Cl}$ (Chloride), Cond (specific conductivity), DOM (dissolved organic matter), DO (dissolved oxygen), Po4 (phosphate), TA (total alkalinity), TDS (total dissolved solids), TH (total hardness), pH (hydrogen-ion concentration), Wt (water temperature). Biotic factors: Chy (Chydoridae abundance), Cld (Cladocera abundance), ClR (Cladocera richness), Cop (Copepoda abundance), Lec (Lecanidae abundance), Lep (Lepadellidae abundance), Rot (Rotifera abundance), RR (Rotifera richness), Rz (Rhizopoda abundance), Zoo (Zooplankton abundance), ZR (Zooplankton richness). 
The canonical correspondence analysis (CCA) with 10 abiotic factors registered cumulative influence of $87.37 \%$ and $75.81 \%$ on zooplankton assemblages at the littoral and semi-limnetic stations, respectively (Figs. 9-10).

\section{Discussion}

The sub-tropical NEHU wetland is characterized by soft, slightly acidic-circum neutral, calcium poor waters with low nutrients, chloride indicating a certain influence of human impact, and total alkalinity attributed to bicarbonate ions. The low specific conductivity is attributed to the leached nature of the soil and weathered condition of rocks due to heavy rainfall in NEI (Sharma 1995; Sharma and Sharma 2020) and lowered buffering capacity of de-mineralized waters (Steinitz-Kannan et al. 1983). ANOVA depicts significant variations of $\mathrm{pH}$, specific conductivity, dissolved oxygen, total alkalinity, and total hardness between stations and months; water temperature and dissolved oxygen indicated significant variations between stations; and calcium, magnesium, chloride, dissolved organic matter, total dissolved solids, phosphate, and nitrate recorded significant monthly variations between the sampling stations. The spatial variations of abiotic factors are hypothesized to the habitat heterogeneity of the two stations.

Our report of 148 species, belonging to 72 genera and 30 families, reveals one of the biodiverse zooplankton assemblages known from any individual lentic environ of the Indian sub-region. This salient feature is hypothesized to the overall environmental heterogeneity of NEHU urban wetland. The biodiversity significance is in contrast to the general pattern of reduced taxonomic richness hypothesized to be expected in highly modified urban aquatic environs (Hill et al. 2017). We thus categorize this urban wetland as 'keystone' system of Meghalaya state of NEI for the conservation of aquatic biodiversity in light of the remarks of Céréghino et al. (2014), Vad et al. (2017), and Oertli (2018). The rich and diverse nature of zooplankton is in contrast to the reports from the floodplain wetlands of Assam (Sharma and Sharma 2008; Sharma and Hatimuria 2017), Bihar (Sanjer and Sharma 1995), Manipur (Sharma 2011a), and West Bengal (Khan 2002, 2003; Ganesan and Khan 2008; Datta 2011; Patra et al. 2011). The richness is distinctly higher than the reports from small water bodies of Arunachal Pradesh (Saikia et al. 2017), Bihar (Kumar et al. 2011, 2015; Singh et al. 2012; Pandey et al. 2013), Chhattisgarh (Mishra et al. 2014), Meghalaya (Sharma and Wanswett 2006), and West Bengal (Halder Mallick and Chakraborty 2015; Patra et al. 2015; Saha et al. 2017; Middya 2017; Midya et al.
2018) from India; and elsewhere from Bangladesh (Islam and Chowdhury 2013), Bhutan (Sharma and Bhattarai 2005) and Myanmar (Twin and Aung 2019). Zooplankton richness is notably higher than the reports from the lakes and reservoirs of Himachal (Jindal and Prajapat 2005; Thakur et al. 2013; Jindal and Thakur 2014), Karnataka (Hulyal and Kaliwal 2008; Kudari and Kanamadi 2008; Majagi and Vijaykumar 2009; Majagi 2014; Anita et al. 2019), Jammu \& Kashmir (Khan 1987; Ahangar et al. 2012; Slathia and Dutta 2013; Sharma and Sharma 2019), Meghalaya (Sharma 1995; Sharma and Lyngdoh 2004; Sharma and Sharma 2020), Mizoram (Sharma and Pachuau 2013), Telangana (Karuthapandi et al. 2016) and Uttarakhand (Sharma and Pant 1985; Mishra et al. 2010; Malik and Panwar, 2016; Sharma and Kumari 2018; Singh and Sharma 2020) states of India. The reports of 148 and 122 species with $90.4 \%$ community similarity affirm high zooplankton homogeneity amongst the stations.

The diverse Rotifera (90 species belonging to 29 genera and 15 families) merit biodiversity interest as $\sim 56.0, \sim 38.0$, and $\sim 23.0 \%$ of the species of this taxon known till date from Meghalaya and NEI (Sharma and Sharma 2019c) and India (Sharma and Sharma 2017a), respectively. The salient features of poor Brachionidae richness and lack of Brachionus spp. noted in our collections are attributed to slightly acidic - circum neutral waters concurrent with the reports of Sharma and Pachuau (2013), Sharma et al. (2016), and Sharma and Sharma (2020), while Brachionidae paucity concurs with the report from Arunachal Pradesh (Saikia et al. 2017). Lecanidae > Lepadellidae collectively comprise $\sim 57.0 \%$ of the rotifer richness and affirm the littoral-periphytic character of the taxon vides Sharma and Sharma (2017a, 2019c). Additional details of Rotifera diversity vis-à-vis new reports (Sharma 2016), species composition, and elements of biogeographic interest are dealt with separately by Sharma et al. (2016). Cladocera, the second speciose group, indicated 36 species belonging to 28 genera and 6 families; it depicts diverse nature in comparison with our conservative estimate of the occurrence of 60-65 species from the tropical and subtropical waters of the Indian subcontinent (Sharma and Michael 1987; Sharma and Sharma 2017b). High richness $(\sim 69 \%)$ of the Chydoridae affirms the littoral periphytic nature of cladoceran assemblages (Sharma and Sharma 2017b).

Higher monthly zooplankton richness at the semi-limnetic > the littoral station is hypothesized to greater habitat diversity of the former region, while ANOVA indicates significant richness variations between stations and months. The zooplankton richness follows oscillating monthly variations at the 
two stations, while peak consortium/sample of 83 species in monsoon (July 2015) and high assemblage of 81 (August 2014) species, noted at the semilimnetic station, are attributed to the possibility of coexistence of many species due to high amount of niche overlap as hypothesized by MacArthur (1965). We categorize these assemblages as 'Zooplankton paradox' vs. small urban wetland; such consortia are hypothesized to the intriguing possibility of the coexistence of a number of species in a relatively unstructured environment of small wetlands (Sharma and Sharma 2019a). Peak monsoon richness at the two stations is affirmed by a positive correlation with water temperature; the latter concurs with the results of Thakur et al. (2013). Further, monsoon peaks concur with the reports from Holmari beel of Assam (Sharma and Hatimuria 2017), Karnataka (Majagi 2014), Meghalaya (Sharma and Wanswett 2006), North Bengal (Datta 2011), and Telangana (Karuthapandi et al. 2016) but deviate from the reports of the post-monsoon peak by Ganesan and Khan (2008) and winter peak by Sharma and Sharma (2020). Zooplankton register 47.2-74.5\% and $55.7-84.0 \%$ community similarities at the littoral and semi-limnetic stations, respectively; 92\% instances record $51-70 \%$ similarities at the former station, while similarity matrix record $61-80 \%$ similarities in $\sim 84 \%$ instances at semi-limnetic station. The hierarchical cluster analysis indicates closer affinities between September-October, March-April, and January-February assemblages while August collection indicates peak species divergence at the littoral station. High affinity is noted only between July-August and maximum divergence is noted during November > February > December collections at the semi-limnetic station. The heterogeneity in monthly richness, affirmed both by community similarities and the differential cluster groupings, is hypothesized to habitat heterogeneity of the two stations. The rotifers contribute to zooplankton richness $\left(\mathrm{r}_{1}=0.908, \mathrm{p}=0.0003 ; \mathrm{r}_{2}=0.915\right.$, $\mathrm{p}=0.0002)$ at the two stations, respectively, and register significant variations between stations and months (vide ANOVA). The report of 46 species in September 2014 (semi-limnetic station) vs. this urban wetland is categorized as 'Rotifera paradox' analogous to the reports of Sharma and Sharma (2019a, 2019b). The community similarities reflect greater rotifer heterogeneity at the former station. Cladocera contributed to zooplankton richness $\left(r_{2}=0.915, p=0.0002\right)$ at the semi-limnetic station and higher similarities affirm lower heterogeneity of Cladocera at the two stations.

Our results highlight low zooplankton abundance with the littoral > semi-limnetic station except in June 2015; ANOVA registers significant variations of abundance between stations and months. The low densities are attributed to soft and de-mineralized waters of NEHU wetland in particular; these remarks correspond with the reports from identical aquatic environs of NEI (Sharma 1995, 2011a; Sharma and Wanswett 2006; Sharma and Sharma 2012, 2020; Sharma and Pachuau 2013; Sharma and Noroh 2020) as well as from Bhutan (Sharma and Bhattarai 2005). The zooplankton follow oscillating monthly variations with higher abundance during warmer months and peak densities during monsoon (August 2014) at both the stations, these are affirmed by positive correlation with water temperature $\left(r_{1}=0.789, p=0.0067 ; r_{2}=0.837, p=0.0025\right)$. The latter concurs with the results of Patra et al (2011), Thakur et al. (2013), and Singh and Sharma (2020) but differ from the inverse correlation indicated by Pandey et al. (2013) and Slathia and Dutta (2013). Further, monsoon peaks concur with the reports from Arunachal Pradesh (Saikia et al. 2017), Assam (Deka and Goswami 2015), Uttarakhand (Thakur et al. 2013), and Myanmar (Twin and Aung 2019) but differ summer peaks listed from wetlands of Bihar (Pandey et al. 2013), Kashmir (Slathia and Dutta 2013), Karnataka (Majagi 2014; Anita et al. 2019) and from winter peaks known from Himachal Pradesh (Sharma and Kumari 2018), Meghalaya (Sharma and Wanswett 2006), Uttarakhand (Malik and Panwar 2016; Singh and Sharma 2020) and West Bengal (Halder Mallick and Chakraborty 2015; Patra et al. 2015). Low and equitable abundance categorizes 'generalist' nature of zooplankton species concurrent with the reports from Himachal Pradesh (Jindal and Prajapat 2005; Jindal and Thakur 2014), NEI (Sharma 1995; Sharma and Lyngskor 2003; Sharma 2011a, 2011b, Sharma and Sharma 2011, 2020; Sharma and Noroh 2020) and Uttarakhand (Malik and Panwar 2016; Singh and Sharma 2020). Rotifera $(42.9 \pm 11.3,44.2 \pm 4.6 \%) \geq$ Cladocera $(40.0 \pm 5.2, \quad 38.4 \pm 4.3 \%)$ contribute to zooplankton abundance at the two stations, respectively but with different spatio-temporal patterns.

Rotifera, an important group, contributes to zooplankton density variations at the littoral $\left(r_{1}=0.915, p=0.0002\right)$ and semi-limnetic $\left(r_{2}=0.825\right.$, $\mathrm{p}=0.003)$ stations. The importance of Rotifera concurs with the reports of Khan $(1987,2003)$, Sanjer and Sharma (1995), Jindal and Prajapat (2005), Jyoti et al (2009), Patra et al. (2011), Sharma (2011a, 2011b), Sharma and Sharma (2011, 2012, 2019c) Pandey et al. (2013), Deka and Goswami (2015), Halder Mallick and Chakraborty (2015), Malik and Panwar (2016), Sharma and Kumari (2018) and Sharma and Noroh (2020). Higher rotifer abundance during warmer months is affirmed by a positive 
correlation with water temperature; the latter concurs with the results of Thakur et al. (2013), Malik and Panwar (2016), and Sharma and Sharma (2020). Peak Rotifera densities during monsoon at the two stations concur with the report from Maghuri beel of Assam (Sharma and Noroh 2020) and the reports of Jyoti et al. (2009), Karuthapandi et al. (2016), Saikia et al. (2017) but differ from summer (Sanjer and Sharma 1995; Patra et al. 2011; Pandey et al. 2013; Sharma and Kumari 2018), winter peaks (Sharma and Hussain 2001; Sharma 2011a; Sharma and Sharma 2011 , 2012) from different states of India. Lecanidae $\left(\mathrm{r}_{1}=0.813, \quad \mathrm{p}=0.004 ; \quad \mathrm{r}_{1}=0.805, \quad \mathrm{p}=0.005\right) \quad$ and Lepadellidae $\quad\left(\mathrm{r}_{1}=0.827, \quad \mathrm{p}=0.003 ; \quad \mathrm{r}_{1}=0.884\right.$, $\mathrm{p}=0.0007$ ), respectively contribute to zooplankton and Rotifera abundance at the littoral station; Lecanidae contributes to zooplankton $\left(r_{2}=0.705\right.$, $\mathrm{p}=0.023)$ and Rotifera $\left(\mathrm{r}_{2}=0.814, \mathrm{p}=0.004\right)$ the semilimnetic station; and Trichocercidae $\left(\mathrm{r}_{1}=0.811\right.$, $\mathrm{p}=0.004)$ and Brachionidae $\left(\mathrm{r}_{1}=0.744, \mathrm{p}=0.0136\right)$ contribute to Rotifera at the littoral station. Lecanidae comprise between $40.0 \pm 6.8$ and $39.3 \pm 6.3 \%$ of Rotifera, while the five Eurotatoria families collectively form notable fractions of zooplankton $(35.5 \pm 7.1,37.6 \pm 4.1 \%)$ and Rotifera $(87.2 \pm 6.7,84.9 \pm 3.3 \%)$ at the two stations, respectively. ANOVA registers significant monthly variations of Rotifera, Lecanidae, Lepadellidae, and Trichocercidae abundance between the stations. Lecanidae and Lepadellidae importance concur with the reports from NEI (Sharma 2011a; Sharma and Sharma 2001, 2008).

Cladocera, another important group, indicates significant density variations between stations (vide ANOVA) and records higher abundance that the reports from Assam (Sharma and Hussain 2001; Deka and Goswami 2015; Sharma and Hatimuria 2017), Kashmir (Khan 1987), Meghalaya (Sharma and Lyngdoh 2004) and Mizoram (Sharma and Pachuau 2013), while it broadly concurs with the report of Sharma and Noroh (2020). The cladocerans follow oscillating monthly variations with peaks during pre-monsoon (June 2015) at both the stations; the latter concur with the reports of Sharma (2011a), Deka and Goswami (2015), Sharma and Noroh (2020), Malik and Panwar (2016), Saikia et al. (2017) and Singh and Sharma (2020). Cladocera is notable for the importance of the Chydoridae $(60.3 \pm 4.5$, $52.7 \pm 8.8 \%$ ) at the two stations, respectively concurrent with the reports of Sharma (2011a, 2011b) and Sharma and Sharma (2008, 2011, 2012); ANOVA indicates significant variations of Chydoridae between the stations. Daphniidae deserved attention at the two stations; Macrothricidae is important at the limnetic station, while Sidiidae deserved limited importance. The four families comprise a significant fraction of Cladocera $(95.1 \pm 1.9,78.8 \pm 8.7 \%)$ and zooplankton $(38.0 \pm 4.6$, $31.3 \pm 4.4 \%$ ) abundance at the two stations, respectively.

Copepoda and Rhizopoda, two sub-dominant groups, indicate low abundance and limited spatial variations at the two stations. Copepoda > Rhizopoda abundance pattern is noted during September 2014January 2015 and again in July 2015 at the littoral station, while Rhizopoda > Copepoda abundance is recorded throughout the study at the limnetic station, except January 2015. Copepoda indicates low abundance at the two stations with significant variations between stations (vide ANOVA). The subdominance of copepods concur with the reports from Assam (Sharma and Sharma 2012; Deka and Goswami 2015; Sharma and Noroh 2020), Himachal Pradesh (Jindal and Prajapat 2005), Jammu \& Kashmir (Jyoti et al. 2009; Sharma and Sharma 2020), Manipur (Sharma 2011a) and Uttarakhand (Malik and Panwar 2016; Singh and Sharma 2020). Monsoon maxima of this group at the two stations concur with the findings of Jindal and Thakur (2014) but deviate from pre-monsoon peaks vides the reports of Ganesan and Khan (2008) and Sharma and Sharma (2020). Copepoda abundance, largely influenced by Cyclopidae, is attributed to the prevalence of stable environmental conditions for these ' $\mathrm{k}$-strategists' as suggested by Allen (1976). Rhizopoda abundance broadly concurs with the report of Sharma and Noroh (2020), it is higher than the results of Sharma and Pachuau (2013) and Sharma and Hatimuria (2017) but differs from the poor abundance reported by Sharma and Sharma (2020). The rhizopods record maxima during monsoon at the two stations. Ostracoda forms an insignificant fraction of zooplankton.

Zooplankton are characterized by high species diversity at the semi-limnetic station > the littoral station; the former station recorded higher diversity throughout the study, except in November 2014; ANOVA depicts significant diversity variations between stations. The limnetic station recorded $\mathrm{H}^{\prime}$ values $>4.0$ during 9 months, while the semi-limnetic station indicated $\mathrm{H}^{\prime}$ values $>4.0$ during 7 months. High zooplankton species diversity of this urban wetland, coupled with low densities of individual species, is hypothesized to fine niche portioning in combination with micro-and macro- habitat heterogeneity as hypothesized by (Segers 2008). The diversity is directly influenced by richness of zooplankton $\left(\mathrm{r}_{2}=0.964, \mathrm{p}<0.0001\right)$, Rotifera $\left(r_{2}=0.875, p=0.0009\right)$ and Cladocera $\left(r_{2}=0.700\right.$, $\mathrm{p}=0.024)$, and abundance of zooplankton $\left(\mathrm{r}_{2}=0.962\right.$, $\mathrm{p}<0.0001)$, Rotifera $\left(\mathrm{r}_{2}=0.827, \mathrm{p}=0.003\right)$ and Lecanidae $\left(r_{2}=0.722, p=0.018\right)$ at the semi-limnetic 
station, while so such relationship is noted at the littoral station. Shannon Weiner diversity index is a suitable option for assessing the health of aquatic biotopes (Wilhm and Dorris 1968). Mean annual diversity values indicate a relatively more clean water nature of the semi-limnetic region while in general NEHU wetland is characterized by a very clean - clean water nature. Low dominance noted at the two sampling stations, shared by a large number of 'generalist' species (Osborne et al. 1976), is hypothesized to the fact that the habitat of this urban wetland has resources for utilization by all species providing a low amount of niche overlap as hypothesized by MacArthur (1965). Low densities and equitable abundance of zooplankton species affirm higher evenness and reiterate that zooplankton are 'generalist' vis-à-vis the general environment of this wetland.

This study depicts the differential spatial influence of individual abiotic parameters on the richness and abundance of zooplankton. Our results affirm the importance of water temperature with a positive influence on zooplankton and Rotifera richness and abundance of zooplankton, Rotifera, and Lecanidae at the two stations, respectively; positive influence on the abundance of Trichocercidae density at the littoral station and Rhizopoda at the semilimnetic station. Besides, dissolved organic matter indicates importance with inverse correlations on zooplankton and Rotifera richness, and abundance of zooplankton, Rotifera and Lecanidae, and zooplankton richness and abundance is inversely correlated with total dissolved solids; Lecanidae abundance is positively correlated with specific conductivity at the former station. Rotifera density is inversely correlated with dissolved organic matter at the semi-limnetic station. The limited and differential influence of individual abiotic factors affirms the reports of Sharma and Hussain (2001), Sharma (2011a), Sharma and Sharma $(2011,2012)$, Sharma and Noroh (2020), and Sharma and Sharma (2020).

The canonical correspondence analysis depicts high but the differential cumulative influence of 10 abiotic factors on zooplankton assemblages at the littoral $(87.37 \%)$ and semi-limnetic (75.81\%) stations, respectively; it broadly concurs with the report of Sharma and Sharma (2020). Also, the former broadly concurs with $84.8 \%$ cumulative variance reported from a subtropical reservoir of Mizoram (Sharma and Pachuau 2013), while our results record higher cumulative influence in contrast to the reports from the floodplain wetlands of NEI (Sharma 2011a; Sharma and Sharma 2012; Sharma and Hatimuria,2017; Sharma and Noroh 2020). CCA coordination biplot at the littoral station indicates
$75 \%$ and $\sim 12 \%$ influence of abiotic factors along axis 1 and 2, respectively with the influence of water temperature on Rotifera abundance; dissolved oxygen on richness and abundance of Cladocera, and abundance of Chydoridae; dissolved oxygen and chloride on zooplankton richness; conductivity on zooplankton abundance; dissolved organic matter and total dissolved solids on Rhizopoda density; and total hardness on Copeopoda abundance. The semilimnetic station indicates $\sim 54 \%$ and $\sim 21 \%$ influence of abiotic factors along axis 1 and 2, respectively with the influence of water temperature on Rotifera richness and abundance; DOM and TDS on Cladocera and Rhizopoda abundance; dissolved oxygen on zooplankton and Cladocera richness; total alkalinity on zooplankton abundance. Our results thus highlight the importance of cumulative influence over the individual influence of abiotic factors, while the impact of biotic factors vs. zooplanktonmacrophytic associations in this urban wetland needs to be assessed.

To sum up, the biodiversity significance of zooplankton of NEHU wetland and its importance as 'keystone' system of NEI vs. lentic environs of the Indian sub-region is hypothesized to overall environmental heterogeneity of this urban wetland. Peak consortia indicating 'zooplankton' and 'Rotifera paradox' hypothesized to the possibility of co-existence of several species due to high amount of niche overlap in the relatively unstructured environment of the small wetland; low zooplankton abundance attributed to 'soft' and de-mineralized waters; and the differential spatial patterns of richness, abundance and diversity indices hypothesized to habitat heterogeneity of the sampled stations are noteworthy. High species diversity, and low dominance, and high equitability attributed to 'generalist' species are notable features; the former depicts the 'very clean - clean water nature' of this wetland. The importance of high cumulative influence vis-à-vis limited spatial influence of individual abiotic factors is noteworthy. This study is an important contribution to zooplankton diversity of small water bodies of the Indian sub-region, and highlights need for the future-focused studies on zooplankton diversity to avoid the proliferation of 'ad-hoc' and 'routine' reports.

\section{Acknowledgments}

The senior author (BKS) is thankful to the Head, Department of Zoology, North-Eastern Hill University, Shillong for laboratory facilities and to K.R. Sounii Pou for help in field collections. The authors have no conflict with research interests. 


\section{References}

Adhikari S, Goswami AR, Mukhopadhyay SK. 2017. Diversity of zooplankton in municipal wastewater contaminated urban pond ecosystems of the lower Gangetic plains. Turk J Zool. 41:464-475. doi:10.3906/zoo-1601-12

Ahangar IA, Saksena DN, Mir FM. 2012. Seasonal variation in zooplankton community of Anchar Lake, Kashmir. Universal J Env Res Tech. 2(4):305-310.

Allen JD. 1976. Life history patterns in zooplankton. Am Nat. 110(971):165-180. doi: 10.1086/283056

Anita SM, Hatti SS, Majagi S, Chitra J. 2019. Assessment of Zooplankton Diversity of Nagaral Dam, Chincholli, Kalaburagi. Res J Life Sci Bioinform Pharmaceut Chem Sci. 5(26): 269-281. doi: $10.26479 / 2019.0502 .20$

APHA. 1992. Standard methods for the examination of water and wastewater (18 ${ }^{\text {th }}$ Ed.). Washington D.C: American Public Health Association. 2538 p.

Céréghino R, Biggs J, Oertli B, Declerck S. 2008. The ecology of European ponds: defining the characteristics of a neglected freshwater habitat. Hydrobiologia. 597:1-6. doi:10.1007/s10750-007-9225-8

Céréghino R, Boix D, Cauchie HM, Martens K, Oertli B. 2014.The ecological role of ponds in a changing world. Hydrobiologia. 723(1):1-6. doi:10.1007/s 10750-013-1719-y

Chopra G, Jakhar P. 2016. Diversity and community composition of zooplankton in three wetlands of Fatehabad, Haryana. Current World Environ. 11(3):851-858. doi:10.12944/CWE.11.3.21

Datta T. 2011. Zooplankton diversity and physicochemical conditions of two wetlands of Jalpaiguri district, India. Int J Appl Biol Pharmaceut Tech. 2(3):576-583.

Deka PP, Goswami MM. 2015. Heleoplankton productivity at lower trophic level in two types of aquaculture ponds, Guwahati, Assam. Int J Fish Aquat Stud.3(1):57-61.

Downing JA, Prairie YT, Cole JJ, Duarte CM, Tranvik LJ, Striegl RG, Mcdowell WH, Kortelainen P, Caraco NF, Melack JM, Middelburg JJ. 2006. The global abundance and size distribution of lakes, ponds, and impoundments. Limnol Oceanogr. 51(5): 2388-2397. doi:10.4319/lo.2006.51.5.2388

Downing JA, Cole JJ, Middelburg JJ, Striegl RG, Duarte CM, Kortelainen P, Prairie YT, Laube KA. 2008. Sediment organic carbon burial in agriculturally eutrophic impoundments over the last century. Global Biogeochem Cy. 22(1):GB1018. doi:10.1029/2006GB002854

Ganesan L, Khan RA. 2008. Studies on the ecology of zooplankton in a floodplain wetland of West Bengal. In: Sengupta M, Dalwani R. editors. Proceeding of Taal 2007 The 12th World Lake Conference. p. 67-73.

Halder Mallick P, Chakraborty SK. 2015. Does intra-site connectivity influence the dynamics of zooplankton metacommunity in freshwater habitats? Turk J Fish Aquat Sc. 15:661-675. doi:10.4194/1303-2712-v15_3_11

Hill MJ, Biggs J, Thornhill I, Briers RA, Gledhill DG, White JC, Wood PJ, Hassall C. 2017. Urban ponds as an aquatic biodiversity resource in modified landscapes. Global Change Biol. 23(3):986-999. doi:10.1111/gcb.13401

Holgerson MA, Raymond PA. 2016. Large contribution to inland water $\mathrm{CO} 2$ and $\mathrm{CH} 4$ emissions from very small ponds. Nat Geosci. 9(3):222-226. doi:10.1038/ngeo2654

Hulyal SB, Kaliwal BB. 2008. Water quality assessment of Almatti reservoir of Bijapur (Karnataka state, India) with special reference to zooplankton. Environ Monit Assess. 139:299-306. doi:10.1007/s10661-007-9835-7

Islam MA, Chowdhury AH. 2013. Limnological status of Trimohini beel of Rajshahi, Bangladesh. J Asiatic Soc Bangladesh, Science. 39(2):173-182. doi:10.3329/jasbs.v39i2.17854

Jindal R, Prajapat P. 2005. Productivity and trophic status of Renuka wetland (Distt. Sirmour, Himachal Pradesh. Indian J Ecol. 32(2):180-183.

Jindal R, Thakur RK. 2014. Hydrobiology and productivity of Kuntbhyog Lake (District Mandi, Himachal Pradesh), India. Int $\mathrm{J}$ Env Eng. 6(4):449-459. doi:10.1504/ijee.2014.067004

Jindal R, Thakur RK, Singh UB, Ahluwalia AS. 2013. Plankton diversity and water quality assessment of three freshwater lakes of Mandi (Himachal Pradesh, India) with special reference to planktonic indicators. Environ Monit Assess. 185(10): 8355-8373. doi:10.1007/s10661-013-3178-3

Jyoti MK, Sharma KK, Sharma J. 2009. Population dynamics and community structure of zooplankton inhabiting in fish pond Jammu, India. Curr World Environ. 4(1):165-169. doi:10.12944/CWE.4.1.26

Karuthapandi M, Rao DV, Innocent X. 2016. Zooplankton composition, diversity and physicochemical features of Bandam Kommu Pond, Medak District, Telangana, India. Proc Zool Soc. 69(2):189-204. doi:10.1007/s12595-015-0142-y

Khan MA. 1987. Observations on zooplankton composition, abundance and periodicity in two floodplain lakes of the Kashmir Himalayan valley. Acta Hydrochem Hydrob. 15(2):167-174. doi:10.1002/aheh.19870150211

Khan RA. 2002. The ecology and faunal diversity of two floodplain Ox-bow lakes of South-Eastern West Bengal. Rec Zool Surv India Occ Paper.195: 1-57.

Khan RA. 2003. Faunal diversity of zooplankton in freshwater wetlands of Southeastern West Bengal. Rec Zool Surv India, Occ Paper. 204:1-107.

Kudari VA, Kanamadi RD. 2008. Impact of changed trophic status on the zooplankton composition in six water bodies of Dharwad district, Karnataka state (South India). Environ Monit Assess. 144: 301-313. doi:10.1007/s10661-007-9993-7 
Kumar U, Kumar SS, Singh PK. 2015. Analysis of seasonal biodiversity of zooplankton in Sahni tola talab (pond) of Sundarpur Bela, Darbhanga district, Bihar. Int J Sci Res. 4(2):70-72.

Kumar P, Wanganeo A, Sonaullah F, Wanganeo R. 2012. Limnological study on two high altitude Himalayan Ponds, Badrinath, Uttarakhand. Int $\mathrm{J}$ Ecosys. 2(5):103-111. doi: 10.5923/j.ije.20120205.04

Kumar P, Wanganeo A, Wanganeo R, Sonaullah F. 2011. Seasonal variations in zooplankton diversity of railway pond, Sasaram, Bihar. Int $\mathrm{J}$ Env Sci. 2(2):1007-1016.

Ludwig JA, Reynolds JF. 1988. Statistical Ecology: A Primer on Methods and Computing. New York: John Wiley \& Sons 337p.

MacArthur RH. 1965. Patterns of species diversity. Biol Rev. 40(4):510-533. doi:10.1111/j.1469-185X.1965.tb00815.x

Magurran AE. 1988. Ecological diversity and its measurement. Croom Helm Limited, London, 179 p. doi:10.1007/978-94-015-7358-0

Majagi S. 2014. Status of wetlands of Chikkballapur district, Karnataka. India. Int J Water Res. 2(2):55-62.

Majagi S, Vijaykumar K. 2009. Ecology and abundance of zooplankton in Karanja reservoir. Environ Monit Assess. 152:451-458. doi:10.1007/s10661-008-0329-z

Malik DS, Panwar P. 2016. Zooplankton diversity, species richness and their distribution pattern in Bhimtal Lake of Kumaun region, (Uttarakhand). Hydrol Current Res. 7(1):1-7. doi:10.4172/2157-7587.1000219

Michael RG, Sharma BK. 1988. Indian Cladocera (Crustacea: Branchiopoda: Cladocera) Fauna of India and adjacent countries Series. Zoological Survey of India, Calcutta $262 \mathrm{pp}$.

Middya S. 2017. Community structure of zooplankton in three different types of water bodies of West Midnapore District, India. J Pharmacy Biol Sci. 12(6-4):21-28. doi: $10.9790 / 3008-1206042128$

Midya S, Bhattacharya S, Islam SS, Ganguly RK, Chakraborty SK. 2018. Observation on freshwater zooplankton and hydrophytes composition in different wetlands of Paschim Medinipur, West Bengal (India). Int J Zool Stud. 3(2):5-9.

Mishra A, Chakraborty SK, Jaiswar AK, Sharma AP, Deshmukhe G, Mohan M. 2010. Plankton diversity in Dhaura and Baigul reservoirs of Uttarakhand. Indian J Fish. 57(3):19-27.

Mishra R, Kanumgo VK, Shrivastava S, Agrawal RK. 2014. Seasonal abundance of zooplankton in five ponds of Raipur city in Chhattisgarh. Int J Fauna Biol Stud. 1(6):78-82.

Moss B, Kosten S, Meerhof M, Battarbee R, Jeppesen E, Mazzeo N, Havens K., Lacerot G, Liu Z, De Meester L, Paerl H, Scheffer M. 2011. Allied attack: climate change and eutrophication. Inland Waters. 1(2):101-105.

doi:10.5268/IW-1.2.359
Mullins ML, Doyle RD. 2019. Big things come in small packages: why limnologists should care about small ponds. Acta Limnol Brasiliensia. 31: e105. doi:10.1590/s2179-975x4119

Oertli B. 2018. Freshwater biodiversity conservation: The role of artificial ponds in the 21 st century. Aquatic Conserv. 28(2):264-269. doi:10.1002/aqc.2902

Osborne A, Wanielista P, Yousuf A. 1976. Benthic fauna species diversity in six central Florida lakes in summer. Hydrobiologia. 48(2):125129. doi:10.1007/BF00040164

Pandey BN, Siddhartha R, Tanti KD, Thakur AK. 2013. Seasonal variation of zooplanktonic community in swamp of Purnia (Bihar), India. Aquatic Biol Res.1(1):1-9.

Patra A, Santra KB, Manna CK. 2011. Ecology and diversity of zooplankton in relation to physicochemical characteristics of water of Santragachi Jheel, West Bengal, India. Journal of Wetlands Ecology. 5:20-39. doi:10.3126/jowe.v5i0.4595

Patra AK, Das V, Datta T, Datidar SG. 2015. Zooplankton fauna of Moraghat forest, a territorial forest of Jalpaiguri district, West Bengal, India. Euro J Exp Biol. 5(1):39-47.

Saha S, Saha T, Basu P. 2017. Seasonal changes in zooplankton and macro-fauna populations of the East Calcutta wetland fish ponds. Proc Zool Soc. 70(2):156-164. doi:10.1007/s12595-016-0173-z

Saikia R, Das T, Gogoi B, Akash K, Vivekanand S, Das DN. 2017. Community structure and monthly dynamics of zooplankton in high altitude rice fish system in Eastern Himalayan region of India. Int J. Life Sci. 5(3):362-378.

Sanjer LR, Sharma UP. 1995. Community structure of plankton in Kawar lake wetland, Begusarai, Bihar: II Zooplankton. J Freshwat Biol. 7:165-167.

Seekell DA, Pace ML, Tranvik LJ, Verpoorter C. 2013. A fractal-based approach to lake size-distributions. Geophys Res Lett. 40(3):517-521. doi:10.1002/grl.50139

Segers H. 2008. Global diversity of rotifers (Rotifera) in freshwater. Hydrobiologia. 595:49-59. doi:10.1007/s10750-007-9003-7

Sharma A, Sharma M. 2019. Zooplankton diversity in relation to physico-chemical parameters in subtropical pond of Jammu, Jammu and Kashmir, India. Biosci Biotech Res Asia. 16(2):425-439. doi:10.13005/bbra/2758

Sharma BK. 1995. Limnological studies in a small reservoir in Meghalaya (N. E. India). In: K.H. Timotius \& F. Goltenboth, editors. Tropical Limnology, II:1-11. Salatiga, Indonesia: Satya Wacana University Press.

Sharma BK. 1998. Freshwater rotifers (Rotifera: Eurotatoria). In: State Fauna Series: Fauna of West Bengal. 3(11):341-461. Zoological Survey of India, Calcutta 
Sharma BK. 2011a. Zooplankton diversity of two floodplain lakes (pats) of Manipur, northeast India. Opusc Zool Budapest. 42(2):185-197.

Sharma BK. 2011b. Zooplankton communities of Deepor beel (a Ramsar site), Assam (N.E. India): ecology, richness and abundance. Trop Ecol. 52(3):291-302.

Sharma BK. 2016. Interesting rotifers (Rotifera: Eurotatoria) from a sub-tropical wetland of Meghalaya: new records. Turk J Zool. 40(3):433-437. doi:10.3906/zoo-1510-20

Sharma BK, Bhattarai S. 2005. Hydrobiological analysis of a peat bog with emphasis on its planktonic diversity and population dynamics in Bumdeling Wildlife Sanctuary, eastern Bhutan. Limnology. 6:183-187. doi:10.1007/s10201-005-0157-6

Sharma BK, Hatimuria MK. 2017. Zooplankton diversity of three floodplain lakes (beels) of the Majuli River Island, Brahmaputra river basin of Assam, northeast India. J Aquac Mar Biol. 6(1):00144. doi:10.15406/jamb.2017.06.00144

Sharma BK, Hussain Md. 2001. Abundance and ecology of zooplankton in a tropical floodplain lake, Assam (N.E. India). Ecol Env Cons. 7(4):397-403.

Sharma BK, Kensibo. 2017. Rotifer assemblages (Rotifera: Eurotatoria) of two wetlands of Nagaland, northeast India: ecosystem diversity and interesting features. Int J Fish Aquac Stud. 5(2):609-617.

Sharma BK, Lyngdoh RM. 2004. Zooplankton communities of Umiam reservoir, Meghalaya (N. E. India): composition, abundance and ecology. Indian J Anim Sci. 74 (6):681-685.

Sharma BK, Lyngskor C. 2003. Plankton communities of a subtropical reservoir of Meghalaya (N. E. India). Indian J Anim Sci. 73(2):88-95.

Sharma BK, Michael RG. 1987. Review of taxonomic studies on freshwater Cladocera from India with remarks on biogeography. Hydrobiologia. 145:29-33. doi:10.1007/BF02530262

Sharma BK, Noroh N. 2020. Zooplankton diversity of three floodplain lakes of the Dibru-Saikhowa Biosphere reserve, upper Assam, northeast India. Int J Aquat Biol. 8(1):189-34. doi:10.22034/ijab.v8i1.730

Sharma BK, Pachuau L. 2013. Zooplankton diversity of a sub-tropical reservoir of Mizoram, Northeast India. Opusc Zool Budapest. 44(1):47-60.

Sharma BK, Pou KRS, Sharma S. 2016. Rich rotifer assemblage (Rotifera: Eurotatoria) of a sub-tropical wetland of Meghalaya, Northeast India: ecosystem diversity and interesting features. Int $\mathbf{J}$ Aquat Biol. 4(3):179-188.

Sharma BK, Sharma S. 1999a. Freshwater Rotifers (Rotifera: Eurotatoria). In: State Fauna Series: Fauna of Meghalaya. 4(9): 11-161. Zoological Survey of India. Calcutta.

Sharma BK, Sharma S. 1999b. Freshwater Cladocerans (Crustacea: Branchiopoda: Cladocera). In: State Fauna Series: Fauna of Meghelaya. 4(9): 469-550. Zoological Survey of India, Calcutta.

Sharma BK, Sharma S. 2000. Freshwater Rotifers (Rotifera: Eurotatoria). In: State Fauna Series: Fauna of Tripura. 4(7): 163-224. Zoological Survey of India, Calcutta.

Sharma BK, Sharma S. 2011. Zooplankton diversity of Loktak Lake, Manipur, India. Journal of Threatened Taxa. 3(5):1745-1755. doi:10.11609/JoTT.o2457.1745-55

Sharma BK, Sharma S. 2012. Diversity of zooplankton in a tropical floodplain lake of the Brahmaputra river basin, Assam (Northeast India). Opusc Zool Budapest. 43(2):187-195+ appendix

Sharma BK, Sharma S. 2017a. Rotifera: Eurotatoria (rotifers) Chapter 7. In: K. Chandra, K.C. Gopi, D.V. Rao, K. Valarmathi, J.R.B Alfred, editors. Current status of freshwater faunal diversity in India. Zoological Survey of India, Kolkata. p. 93-113.

Sharma BK, Sharma S. 2017b. Crustacea: Branchiopoda: Cladocera) Chapter 14. In: K. Chandra, K.C. Gopi, D.V. Rao, K. Valarmathi, J.R.B Alfred, editors Current status of freshwater faunal diversity in India. Zoological Survey of India, Kolkata. p. 199-223.

Sharma BK, Sharma S. 2019a. The biodiverse rotifers (Rotifera: Eurotatoria) from small wetlands of the Brahmaputra river floodplains of lower and upper Assam, Northeast India. Journal of Limnology and Freshwater Fisheries Research. 5(3):187-196. doi:10.17216/LimnoFish.515981

Sharma BK, Sharma S. 2019b. The biodiverse rotifers (Rotifera: Eurotatoria) of the floodplain wetlands of Barak valley of Assam state, northeast India. Opusc Zool Budapest. 50(1):3-15. doi:10.18348/opzool.2019.1.3

Sharma BK, Sharma S. 2019c. The biodiverse rotifers (Rotifera: Eurotatoria) of Northeast India: faunal heterogeneity, biogeography, richness in diverse ecosystems and interesting species assemblages. Bonn Zool Bull. 68(1):147-162. doi:10.20363/BZB-2019.68.1.147

Sharma BK, Sharma S. 2020. Zooplankton diversity of a subtropical reservoir of Meghalaya, northeast India with remarks on spatial and temporal variations. Opusc Zool Budapest. 51(1):67-86. doi:10.18348/opzool.2020.1.67

Sharma BK, Wanswett D. 2006. Zooplankton of a subtropical fish pond of high rainfall region of Meghalaya (N.E. India): composition and ecology. Rec Zool Surv India. 106(1):69-80.

Sharma PC, Pant MC. 1985. Species composition of zooplankton in two Kumaun Himalayan Lakes (U.P., India). Arch Hydrobiol. 102:387-403.

Sharma RC, Kumari K. 2018. Seasonal variation in zooplankton community and environmental variables of sacred Lake Prashar Himachal Pradesh, India. Int J Fish Aquac Stud. 6(2):207-213.

Sharma S, Sharma BK. 2008. Zooplankton diversity in floodplain lakes of Assam. Rec Zool Surv India, Occ Paper No. 290:1-307.

Singh RK, Pandey MK, Kumari R, Ranjan P. 2012. Study on the diversity and seasonal variation of zooplankton in Mahendra Nath Pond, Siwan, Bihar. Int Pharmaceut Biol Arch. 3(4):867-870.

Singh S, Sharma RC. 2020. Zooplankton diversity and 
potential indicator species for assessment water quality of high altitude wetland, Dodi Tal of Garhwal Himalaya, India. Academia Arena.12(5):1-16. doi:10.7537/marsaaj120520.01

Slathia S, Dutta SPS. 2013. Hydrobiological study of a subtropical Shiwalik Lake, Jammu, J \& K (India). Int J Chem Env Biol Sci. 1(1):143-148.

Steinitz-Kannan M, Colinvaux P A, Kannan R. 1983. Limnological studies in Ecuador: 1. A survey of chemical and physical properties of Ecuadorian Lakes. Arch Hydrobiol. Supplement 65: 61-105.

Thakur RK, Jindal R, Singh UB, Ahluwalia AS. 2013. Plankton diversity and water quality assessment of three freshwater Lakes of Mandi (Himachal Pradesh, India) with special reference to planktonic indicators. Environ Monit Assess. 185: 8355-8373. doi:10.1007/s10661-013-3178-3

Twin YY, Aung SM. 2019. Seasonal occurrence of zooplankton at the pond of Botataung Pagoda, Botataung township, Yangon Region, Myanmar. Int J
Innovative Sci Res Tech. 4(5):991-995.

Tyor AK, Chopra G, Kumari S. 2014. Zooplankton diversity in shallow lake of Sultanpur National park, Gurgaon (Haryana). Int J Appl Biol Pharceut Tech. 5(1):35-49.

Vad CF, Péntek A, Cozma NJ, Földi A, Tóth A, Tóth B, Böde NA, Móra A, Ptacnik R, Ács E, Zsuga K, Horvátha Z. 2017. Wartime scars or reservoirs of biodiversity? The value of bomb crater ponds in aquatic conservation. Biol Conserv. 209:253-262. doi:10.1016/j.biocon.2017.02.025

Verpoorter C, Kutser T, Seekell DA, Tranvik LJ. 2014. A global inventory of lakes based on high-resolution satellite imagery. Geophys Res Lett. 41(18):6396-6402. doi:10.1002/2014GL060641

Wilhm JL, Dorris TC 1968. Biological parameters for water quality criteria: BioScience, 18(6): $477-481$. doi: $10.2307 / 1294272$ 